\title{
A PROPOSED AMENDMENT TO RESOLVE THE "REMAINING UNPAID" PARADOX OF SECTION 60c OF THE BANKRUPTCY ACT
}

A PRIAIE objective of the Bankruptcy Act is to secure equal distribution of a debtor's assets among creditors of the same class. ${ }^{1}$ In furtherance of this policy, Section 60a defines certain payments made within four months of bankruptcy as preferential, ${ }^{2}$ and Section $60 \mathrm{~b}$ authorizes the trustee in bankruptcy to require that such payments be returned to the estate for the benefit of all general creditors. ${ }^{3}$ Section $60 \mathrm{c}$ seeks to promote fairness with regard to such voidable preferences ${ }^{4}$ and to encourage new credit to insolvent debtors ${ }^{5}$ by providing:

1. See, e.g., Straton v. New, 283 U.S. 318, 320, 321 (1931); Canright v. General Finance Corp., 35 F. Supp. 841,844 (E.D. Ill. 1940). See also 3 Collter, Basiknurtcr If 60.01 (14th ed, Moore \& Oglebay, 1941) ; 1 Resington, Bankrumer $\$ \$ 16,17$ (5th ed., Henderson, 1950).

2. "A preference is a transfer, as defined in this title, of any of the property of a debtor to or for the benefit of a creditor for or on account of an antecedent debt, made or suffered by such debtor while insolvent and within four months before the filing by or against him of the petition initiating a proceeding under this title, the effcet of which transfer will be to enable such creditor to obtain a greater percentage of his debt than some other creditor of the same class." 30 Sr.1T. 562 (1S9S), as amended, 11 U.S.C. \$ 96(a) (Supp. 1952). See 3 Collme, op. cit. supra note 1, IIT 60.02, 60.07-60.35; 4A REAIINGTON, op. cit. supra note $1, \$ \$ 1657-1702$.

3. 30 STAT. 562 (1898), as amended, 11 U.S.C. § 96(b) (1946).

However, even if there is a preference under $\S 60 \mathrm{a}$, there can be no avoidance under $\$ 60 \mathrm{~b}$ unless the transferee had reasonable cause to believe the debtor insolvent at the time of payment. Such payments are merely technical prefernces. 3 CoLures, of. cil. sisfra note 1 , fit 60.02, 60.52-60.56; 4 A REMIngron, of. cit. stipra note 1 , $\$ \$ 1657,1658,1703-1712$.

There are several other sections available to the trustee to secure cquality of distribution. Section 67 a invalidates every lien obtained by judicial procecdings within four months of bankruptcy "if at the time when such lien was obtained such person was insolvent or ... if such lien was sought and permitted in fraud of this title" 30 STat. 564 (1898), as amended, 11 U.S.C. $\$ 107$ (a) (1946). See 4 ColnIEs, op. cit. sitpra note 1, ifl 07.0367.19. Section 67d defines fraudulent transfers and ordinarily allows the trustee to avoid them. 30 Stat. 564 (1898), as amended, 11 U.S.C. $\$ 107$ (d) (1946). See 4 CuLLIES, of. cit. supra note 1 fif $67.29-67.43$. Section $70 \mathrm{c}$ gives the trustee the status of a lien creditor as to all property of the bankrupt at the date of bankruptcy. 30 Sr.1r. 565 (1898), as amended, 11 U.S.C. $\$ 110$ (c) (Supp. 1952). 4 CoLLIER, op. cit. supra note 1, if 70.45-70.65. Section 70e allows the trustee to avoid any transfer made or suffered or obligation incurred by a debtor "which, under any Federal or State law applicable thereto, is fraudulent as against or voidable for any other reason by any creditor of the debtor." 30 Sr.s. 562 (1898), as amended, 11 U.S.C. \$ $110(\mathrm{e})$ (1946). See Collier, op. cit. supra note 1, III 70.69-70.95.

A trustee may often have a choice of sections in order to avoid a pre-bankruptcy transfer but sometimes such transfers will not come within any section. See 3 CuLusen, op. cit. sitpra note 1, I 60.01 .

4. See, e.g., Walker v. Wilkinson, 296 Fed. 850, 852 (5th Cir. 1924) ; Gans v. Ellison, 114 Fed. 734, 736 (3d Cir. 1902) ; Atlas v. Eastern Yarn Arills, Inc., 27 F. Supp. 478, 479 (E.D.N.Y. 1939).

5. Courts have recognized that payment of debts encourages new credit. Sie, c.g., C. S. 
"If a creditor has been preferred, and afterwards in good faith gives the debtor further credit without security of any kind for property which becomes a part of the debtor's estate, the amount of such new credit remaining unpaid at the time of the adjudication in bankruptcy may be set off against the amount which would otherwise be recoverable from him."

However, the meaning of Section $60 \mathrm{c}$ has been obscured by conflicting judicial interpretations. ${ }^{7}$ Moreover, even if applied literally, it will produce restults inconsistent with its underlying policy. ${ }^{8}$

Morey Mercantile Co. v. Schiffer, 114 Fed. 447, 449 (8th Cir. 1902); Kimball v. E. A. Rosenham Co., 114 Fed. 85, 87, 88 (8th Cir. 1902). See also 3 Couner, op. cit. supra note 1 , at 248-9. If the creditor knows the debtor is insolvent, the payment may be a preference and therefore not likely to be much of an inducement, since it may be necessary to return it. But if $\S 60 \mathrm{c}$ were amended to allow a set-off of all preferential payments extended so long as they did not exceed the amount of the new credit, creditors would be more willing to extend new credit. An amendment to accomplish this result is proposed p. 302 infra.

6. 30 STAT. 562 (1898), 11 U.S.C. $\$ 96(c)$ (1946).

Although most of the avoidance sections have undergone frequent revisions, 3 Coulder, op. cit. supra note 1 , Iा $60.05,60.06 ; 4$ id. IाT $67.02,70.02,70.03$; $\$ 60 \mathrm{c}$ has remaincd unchanged since its original enactment in 1898. 3 id. $\llbracket 60.67 ; 4$ A REMuNGToN, op. cil. supra note $1, \S 1719$. Thus certain aspects of this section seem well-settled. The "good faith" requirement does not mean that the creditor must be unaware of the debtor's insolvency; it merely requires that the money be given for an honest purpose and that the creditor not act in such a way as intentionally to defeat the act. See, e.g., Kaufman v. Tredway, 195 U.S. 271, 274-5 (1904). The "further credit" entitled to be set off must be given without security of any kind. See, e.g., In re Talbot Canning Corp., 35 F. Supp. 680, 687 (D. Md. 1940). It must become a part of the debtor's estate but it need not remain a part of it until bankruptcy and the creditor need not show what the debtor did with it. See, e.g., Kaufman v. Tredway, 195 U.S. 271, 274-5 (1904). Finally, the new credit must be given after the creditor has already received a preference, c.g., Robie v. Meyers Equipment Co., 114 F. Supp. 177, 182 (D. Minn. 1953), and it can be set off only against antecedent preferential payments, e.g., Robie v. Meyers Equipment Co., supra; Price v. Derbyshire Coffee Co., 128 App. Div. 472, 112 N.Y. Supp. 830 (1908). But cf. Walker v. Wilkinson, 296 Fed. 850 (5th Cir. 1924).

One court has said that the $\$ 60 \mathrm{c}$ set-off against recovery of a preference is not cxclusive; whenever a set-off will promote equality of distribution annong creditors of the same class, as determined by the entire transaction between the creditor and bankrupt, the set-off is proper. Walker v. Wilkinson, supra at 853. Cf. Gans v. Ellison, 114 Fecl. 734, 737 (3d Cir. 1902).

Section $60 \mathrm{c}$ should be distinguished from Section 68, 30 STAT. 562 (1898), as amended, 11 U.S.C. \& 108 (1946), which allows a set-off in cases where there are mutual debts and mutual credits between the bankrupt's estate and a creditor. The former may be invoked although the bankrupt has no debt due from the creditors. In some situations, however, $\S 60 \mathrm{c}$ and $\S 68$ may be asserted in the same action. 3 CoLliEk, op. cit. supra note $1, \pi 60.67 ; 4$ CollIER, op. cit. stpra note 1, ๆ 68.02 .

7. Compare the judicial theories applied in Jaquith v. Alden, 199 U.S. 78 (1902); Walker v. Wilkinson, 296 Fed. 850 (5th Cir. 1924) ; Grandison v. National Bank of Commerce of Rochester, 231 Fed. 800 (2d Cir.), cert. denied, 242 U.S. 644 (1916); In re Acc Fruit \& Produce Co., 49 F. Supp. 986 (S.D.N.Y. 1943); Talty v. Ross, 14 F.2d 240 (D. Mass. 1926).

8. See text at notes $22-43$ infra. 
A major source of judicial confusion has been the application of the "running account" or "net result" rule to situations where the use of Section 60e was appropriate. 9 This rule was applied where there was an open account between parties regularly engaged in business, payments being made at various times and credit extended at others. ${ }^{10}$ If the creditor had no knowledge of the debtor's insolvency, ${ }^{11}$ only the net result of all transactions within the four month period was considered. ${ }^{12}$ Instead of classifying all payments as preferential and then allowing a set-off, payments were regarded as preferential under Section 60 a only to the extent they exceeded the new credit.

Theoretically this "net result" rule became obsolete in $1903 .{ }^{13}$ It never applied when the creditor had reasonable cause to believe the debtor insol-

9. See, e.g., In re Fred Stern \& Co., 54 F.2d 478 (2d Cir. 1931) ; Talty v. Ross, 14 F.2d 240 (D. Miass. 1926). See also 3 CoLx.rer, op. cit. supra note 1, if 57.19, 60.23, 60.67; 4A REAINGTON, op. cit. stpra note $1, \S 1719$.

Although the "net result" doctrine and $\$ 60 \mathrm{c}$ appear similar, there are important differences between the two. "Section $60 \mathrm{c}$ will apply to isolated transactions; there is no requirement for an open, continuing series of transactions between creditor and debtor as in the running account situation. On the other hand, $\$ 60 \mathrm{c}$ does require that there be a credit subsequent to the voidable preferential transfer. This is not the case under the 'net result rule' The rule has been applied even though the last transaction in the series was a payment by the debtor." 3 Collier, op. cit. supra note 1, at 1057. Cf. Campanella v. Licbowitz, 103 F.2d 252, 253-4 (3d Cir. 1939); In re Colton Export \& Import Co., 121 Fed. 663, 604 (2d Cir. 1903).

10. "Where a creditor has a claim for a balance due against an insolvent debtor afterwards adjudicated a bankrupt, upon an open account for goods sold and delivered four months before the adjudication in bankruptcy, and during said period makes a number of sales of merchandise on credit to the insolvent debtor, which becomes a part of the debtor's estate, and during the same period receives payments of sums on account, from time to time, which payments are received in good faith without knowledge of the debtor's insolvency on the part of the creditor, the sales exceeding in amount during said period the payments made during the same time, has the creditor under such circumstances received a preference which he is obliged to surrender before his claim shall be allowed under the bankruptcy act?' . . . The first question is answered in the negative on the authority of Jaquith v. Alden, 189 U.S. 78." Yaple v. Dahl-Mrillikan Grocery Co., 193 U.S. 526, 527 (1904). See also Joseph Wild \& Co. v. Provident Life \& Trust Cu., 214 U.S. 292 (1909) ; C. S. Morey Mercantile Co. v. Schiffer, 114 Fed. 447 (8th Cir. 1902).

11. Matter of Farmers' Store \& Supply Co., 214 Fed. 505, 506 (D.WW. Va. 1914). See also 3 Collier, Bankruptcy 249, 847-8 (14th ed, Mfoore \& Oglebay, 1941) ; 4A ResmicTON, BANKRUPTCY $\$ 1719$ (5th ed., Henderson, 1950).

12. See, e.g., cases cited note 10 supra. See also 3 CoLLIER, op. cil. supra note 11, III 57.19, 60.23, 60.67; 4A Rearnoton, op. cit. supra note $11, \S 1719$.

13. Prior to 1903 it was necessary for a creditor to surrender technical as well as voidable preferences before he could prove his claim under $\$ 57 \mathrm{~g}$. Pirie v. Chicago Title \& Trust Co., 182 U.S. 438 (1901). Since technical preferences could not be avoided by the trustee, the creditor had the option of either surrendering them and proving his claim against the estate or keeping them and giving up his claim. However, a 1903 amendment provided that technical preferences need not be surrendered before one can prove his chaim. 32 Stat. 799 (1903), as amended, 11 U.S.C. $\$ 93(g)$ (1946). See 3 Collier, op. cil. subra note 11 , at $110,250,251,766-8,1054-5$. 
vent ; ${ }^{14}$ conversely, if the creditor had no reason to believe the debtor insolvent any preference would be merely technical, ${ }^{15}$ and since 1903 it has not been necessary to return such preferences. ${ }^{16}$ Nevertheless, several cases since 1903 have seemed willing to apply the rule to running accounts even when the creditor had reason to believe the debtor was insolvent. ${ }^{17}$ Moreover, courts professing to apply Section 60c were sometimes so influenced by the "net result" doctrine that they confused the two or applied Section $60 \mathrm{c}$ without adhering to its requirements. ${ }^{18}$

Ordinarily, the same result is reached either by calling everything a preference and applying Section $60 \mathrm{c}$ or by applying the "net result" rule. In the typical case a large debt exists at the start of the four month period and all preferential payments can be applied to it, thus leaving the new credit completely unpaid.19 For example, assume that prior to the four month period the debtor $(D)$ owed the creditor $(C) \$ 50,000$. Sometime within the period $D$ paid $C$ a $\$ 7000$ preference. Subsequently $C$ advanced new credit of $\$ 5000$ to $D$. If the "net result" rule is followed there is a preference of $\$ 2000$, the amount by which the debtor's estate was diminished within the four months. ${ }^{20}$ If Section $60 \mathrm{c}$ is strictly applied, the $\$ 5000$ unpaid new credit can be set off

14. See authorities cited note 11 supra.

15. See note 3 supra.

16. See note 13 supra.

Thus it has been suggested that "the rule was a product of its time, namely a time when preferences were deemed to be subject to surrender for the sole reason that they were technically preferences, irrespective of the creditor's knowledge of the debtor's insolvency. It was designed to mitigate the rule of Pirie v. Chicago Tille \& Trust Co. which held that anything amounting to a technical preference under $\S 60 \mathrm{a}$ had to bo surrendered before a claim of the same creditor could be allowed. The reason for the rule would thus seem to have vanished in 1903 , when, as previously pointed out, $\$ 57 \mathrm{~g}$ was amended so as to require surrender only in certain cases of voidable transactions, which in turn required some intent or knowledge on the part of the creditor amounting to bad faith. Accordingly, the rule may now be considered as largely obsolete. . . " 3 Collier, op. cit. stipra note 11, at 249-50. See Campanella v. Liebowitz, 103 F.2d 252, 253 (3d Cir. 1939).

The "net result" rule has been severely criticized. See Judge Learned Hand"s comments in Wilcox v. Goess, 92 F.2d 8, 12 (2d Cir. 1937); In re Fred Stern \& Co., 54 F.2d 478, 481 (2d Cir. 1931). And see 3 Collier, op. cit. supra note 11, at 848-9.

17. In re Marley-Morse Co., 275 Fed. 832 (7th Cir. 1921); Dunlap v. Seattle Nat. Bank, 93 Wash. 568, 161 Pac. 364 (1916). Cf. Walker v. Wilkinson, 296 Fed. 850 (5th Cir. 1924); In re Fred Stern \& Co., 54 F.2d 478 (2d Cir. 1931). Contra: Chisholm v. First Nat. Bank of Leroy, 269 Ill. 110, 109 N.E. 657 (1915). The net result rule was judicially developed to avoid results courts regarded as inequitable. Therefore, if nccess sary to achieve equitable results, courts might in the future discard the requirement that creditors have no reason to believe the debtor insolvent.

18. See 3 Collier, op. cit. supra note 11, at 251-2.

19. See, e.g., the fact situations in, In re Evansville Broom Co., 29 F.2d 643 (7th Cir. 1928); Atlas v. Eastern Yarn Milis, Inc., 27 F. Supp. 478 (E.D.N.Y. 1939).

20. See note 12 stupra. This assumes that the only transactions during the period wore the $\$ 7000$ payment and $\$ 5000$ new credit. 
against the $\$ 7000$ preference, ${ }^{21}$ again resulting in an obligation to repay $\$ 2000$.

A problem arises, however, if substantially all of the new credit is repaid. Section 60 c clearly says that "the amount of such new credit rcmaining unpaid at the time of . . . bankruptcy may be set off." 22 If the strict wording of the statute is followed, some unusual results are obtained. Consider the following example involving a series of transactions and repayment of much of the new credit:

$$
C \text { advances to } D
$$

$D$ pays $C$

(all voidable preferences)

Jan. $1 \quad \$ 1000$

4 month period begins and $C$ knows $D$ is insolvent Sept. 2

Sept. 21

1000

Oct. 2

Oct. 15

1000

Nov. 10

Nov. 25

Dec. 2

Dec. 15

$\$ 1000$

1000

900

1000

Filing of petition in bankruptcy

The creditor has extended credits of $\$ 4000$, and $\$ 3000$ of this is new credit extended after a preference. ${ }^{23}$ The debtor has repaid $\$ 3500$. If the "net result" rule is followed, $\$ 500$ of the payments to $C$ is a preference since the net result of the transactions within the four month period decreased the estate of the debtor by $\$ 5 \mathrm{CO}^{24}$ The creditor must return $\$ 500$ and become a general creditor for $\$ 1000 .{ }^{25}$ However, a court might consider the transactions as coming in pairs, in which case there would be unpaid credits of $\$ 100$ on the third pair of transactions (Oct. 15 and Nov. 10) and $\$ 400$ on the fourth pair (Nov. 25 and Dec. 2). ${ }^{26}$ Here $C$ could claim $\$ 500$ as a general creditor with-

21. This assumes that the $\$ 7000$ payment was applied to the previous debt of $\$ \$ 0,000$.

22. 30 Stat. 562 (1S98), 11 U.S.C. \$96(c) (1946) (emplasis added).

23. The payment on Sept. 2 was a preference and, according to $\S(0 c$, unly new credit extended after a preference is entitled to be set off. Therefore, the advances on Sept. 21, Oct. 15, and Nov. 15 fall within $\$ 60 c$, but the advance on Jan. 1 does not.

24. See note 12 supra. In computing the preference under the "net result" rule, the advance on Jan. 1 would be omitted since it is not within the four month period. Thus, within the four months there were advances of $\$ 3000$ and payments of $\$ 3500$. The debtor's estate in that period had been depleted by $\$ 500$ and that is the preference that would have to be returned.

25. Since this $\$ 500$ is a preference and $C$ knew $D$ was insolvent, $C$ would have to return it under $\S 60 \mathrm{~b}$. See note 3 supra. He would then stand on an equal basis with all other creditors of his class in trying to collect his claim for $\$ 1000$.

26. A court might say that each pair of transactions (i.e., Jan. 1 \& Sept. 2, Sept. 21 $\&$ Oct. 2, Oct. $15 \&$ Nov. 10, Nov. 25 \& Dec. 2) constituted a single transaction and hence that no credit was extended except in the last two pairs where the credit execsdcd the payment. Some cases say that if the advances of credit and the payments form a single 
out repaying anything. ${ }^{27}$ Finally, a court might say there was new credit of $\$ 3000$ which could be set off only against the antecedent payments of $\$ 29000^{28}$ $C$ would have to return the last payment of $\$ 600$ and become a general creditor for $\$ 1100$. All of the foregoing alternatives appear equitable. ${ }^{20}$ The difficulty

transaction the payments are not preferences. In re Perpall, 271 Fed. 466,468 (2d Cir. 1921 ) ; Bridges v. Hart, 200 N.C. $685,687,158$ S.E. 242,243 (1931).

But if the payment is made for an antecedent debt, it is a preference, even if the time between the extension of credit and payment is very short. In $r \varepsilon$ Great Lakes Lumber Co., 8 F.2d 96, 97 (W.D. Pa. 1925) ; Seattle Ass'n of Credit Men v. Daniels, 15 Wash. 2d 393, 397, 130 P.2d 892, 894 (1942). In National City Bank v. Hotchkiss, 231 U.S. 50, 58 (1913), the Court refused to find a single transaction when a bank advanced moncy to a brokerage firm early in the day, but later in the day demanded and obtained collateral security. Another court, in holding that payments regularly made within 10 days were not cash transactions, said: "If the parties, by agreement, can treat a sale of goods on 10 days' time as a cash transaction, they may also, by agreement, treat a sale on 30 or 60 days' or longer as a cash transaction, and practically defeat the operation of sections $57 \mathrm{~g}$ and $60 \mathrm{a}$ of the bankrupt act ... . A sale of goods to be paid for in 10 or 30 (dalys is not, in fact, a cash transaction, and cannot, by agreement of the parties, or a usage of merchants, be regarded as such within the meaning of the bankrupt law." In re John Morrow \& Co., 134 Fed. 686, 687-8 (S.D. Ohio 1901).

Thus, it seems probable that a court would not treat the transactions in the above hypothetical as coming in pairs. Instead, each pair would probably be treated as an extension of credit and a preferential payment.

27. Since a court following this theory would say that none of the payments were preferences, there would be nothing for $C$ to return. He would have merely advanced credit of $\$ 500$ which he could claim as a general creditor.

28. Most courts hold that the new credit can be set off only against antecedent preferential payments. E.g., Robie v. Myers Equipment Co., 114 F. Supp. 177 (D. Minn. 1953) ; Price v. Derbyshire Coffee Co., 128 App. Div. 478, 112 N.Y. Supp. 830 (1908). But cf. Walker v. Wilkinson, 296 Fed. 850 (5th Cir. 1924). Thus, the Sept. 21 credit could be set off against the Sept. 2 payment, Oct 15 against Oct. 2, and Nov. 25 against Nov. 10. Under this approach $\$ 2900$ of payments have subsequent credit to offsct; but as there is no subsequent credit to offset the Dec. 2 payment of $\$ 600$, it would have to be returned.

29. Since each of these alternatives appears equitable, a court might follow one of them rather than apply $\S 60 \mathrm{c}$ strictly. Courts have consistently shown a desire to help the individual creditor. Thus, they developed the "net result" rule which greatly aided individual creditors by allowing them to retain payments which they would otherwise have had to return. See notes 9-12 supra. Before 1903 many courts interpreted $\S 60 \mathrm{c}$ broadly to allow a set-off against technical as well as voidable preferences. E.g., Gans v. Ellison, 114 Fed. 734 (3d Cir. 1902) ; McKey v. Lee, 105 Fed. 923 (7th Cir. 1901); In rc Topliff, 114 Fed. 323 (D. Mass. 1902), Contra: In re Oliver, 109 Fed. 784 (W.D. Mo. 1901). Such a broad interpretation of $\$ 60 \mathrm{c}$ clearly helped the individual creditor since, otherwise, he would have had to return these technical preferences before he could prove his claim under $\S 57 \mathrm{~g}$. See note 13 supra.

There has been a long struggle between trustees in bankruptey and creditors over the transactions that could be avoided. Congress has made a continual effort to increase the avoidance powers of trustees so that all creditors of the same class would be treated equally. But courts repeatedly developed doctrines such as "relation back" and "pocket lien" that favored certain creditors over other creditors of the same class. Sec 3 Colduks, Bankruptcy If $60.37,60.39,60.50$ (14th ed., Moore \& Oglebay, 1941); Kupfer, The 
is that each is contrary to the wording of the statute..$^{30}$ If the statute is followed and only the new credit remaining umpaid is set off, a set-off of only $\$ 500$ would be allowed. The creditor would have to repay $\$ 3000$ and become a general creditor for $\$ 3500.31$ The Second Circuit has already reached such a result. ${ }^{32}$

Thus a creditor may often be better off if he is not paid in full. Assume that at the start of the four month period $D$ owed $C \$ 1000$. Thereafter $D$ paid $C$ a $\$ 1000$ preference and $C$ subsequently advanced new credit of $\$ 1000$. If these were the only transactions between the two, the preferential payment would apply to the prior debt and the new credit would remain unpaid. Therefore, the $\$ 1000$ unpaid new credit can be set off against the preferential payment. $C$ can keep $\$ 1000$, repay nothing, and become a general creditor for $\$ 1000.33$ But if, after the above transactions and before bankruptcy, $D$ paid $C$ an additional $\$ 1000$, so that at the time of bankruptcy he owes $C$ nothing, an extraordinary result is obtained. Under such circumstances there is no new credit remaining unpaid and, according to the strict wording of Section $60 \mathrm{c}, C$ has nothing to set off. Thus $C$ must repay the entire $\$ 2000$ and become a general creditor for that amount. Hence, he would have been well-advised to refuse the last payment. $^{34}$

Similar problems may arise whenever a debtor owes a creditor bolh for credit extended before the four month period and for credit extended within the period. The debtor might specifically apply payments to the new credit,

Recent Amendment of Section 60a of the Bankrstptcy Act, 24 J.N.A. ReF. BAskr 86 (1950). Although these particular doctrines have probably been abolished by subsequent congressional action, 52 Stat. 869 (1938), 64 Stat. 24 (1950), as amended, 11 U.S.C. $\$ 96$ (a) (Supp. 1952), they indicate a judicial attitude adverse to a literal applieation of the Bankruptcy Act.

30. "Where the Bankruptcy Act is silent, equitable principles will govern. But the equitable powers of the court are to be exercised within the limits laid down by the Act and subject to and consistent with any specific provisions contained in it." 1 Cousies. op. cit. stipra note 29, at 165 . See 1 RENINGTON, BankRuptCr $\$ 22$ (5th ed., Henderson, 1950).

31. There is only $\$ 500$ remaining unpaid since $C$ has advanced $\$ 4000$ and been repaid $\$ 3500$. $C$ can set this $\$ 500$ unpaid new credit off against the $\$ 3500$ preferential payments which he would otherwise have to return. Thus, he can keep only \$500 and must return $\$ 3000$.

32. Grandison v. National Bank of Commerce, 231 Fed. 800 (2d Cir.), cert. devied 242 U.S. 644 (1916). A New York district court subsequently reached what appears to be a contrary result. In re Ace Fruit \& Produce Co., 49 F. Supp. 986 (S.D.N.Y. 1943).

33. This is the ideal situation for $C$ under a strict interpretation of $\S$ coc. It arises when $C$ is paid all of the credit extended prior to the start of the four month period plus half of the difference between the old debt and the new credit if the new credit exceeds the old debt. If the old debt exceeds the new credit, $C$ will not want to be repaid any of the new credit. This, of course, presumes that the new credit meets all the requirements of $\S 60 \mathrm{c}$.

34. The payment of the final $\$ 1000$ has almost certainly cost $C$ money, since he will almost never receive full payment of his debt as a general creditor. See the statistics compiled in Moore \& Countryanan, Debtor's and Creditor's Rigats 168 (1951). 
leaving the older debt unpaid ;3 indeed, an uninformed creditor might insist on this as a condition for the extension of the new credit. ${ }^{30}$ But then there would be less new credit "remaining unpaid" at the time of bankruptcy and the creditor would have to repay part of the preferences. ${ }^{37}$

To take a similar hypothetical involving a larger number of transactions, consider the following:

$\begin{array}{lcc} & C \text { advances to } D & \begin{array}{c}D \text { pays } C \\ \text { (all preferences) }\end{array} \\ \text { Jan. 1 } & \$ 1000 & \\ \text { Aug. 15 } & \text { Four month period begins and } C \text { knows } D \text { is insolvent. } \\ \text { Sept. 1 } & 1000 & 1000 \\ \text { Sept. 7 } & & \\ \text { Sept. 18 } & 1000 & 1000 \\ \text { Oct. 12 } & 1000 & 1000 \\ \text { Oct. 27 } & & \\ \text { Nov. 2 } & 1000 & 1000 \\ \text { Nov. 26 } & \text { Filing of petition in bankruptcy } & \\ \text { Dec. 12 } & \end{array}$

Assume that all payments to $C$ met all the requirements of voidable preferential payments and that all advances to $D$ within the four months period met all the requirements of new credit under $\S 60 \mathrm{c}$ and were not given for present consideration, there being an antecedent debt in each case. $C$ has advanced new credit of $\$ 4000$ and total credit of $\$ 5000$. He has been repaid $\$ 4000$. There is new credit remaining unpaid of only $\$ 1000$ to set off against the $\$ 4000$ preferences. Thus, $C$ can keep only $\$ 1000$. He must return $\$ 3000$ and become a general creditor for $\$ 4000$. $C$ would have been better off if he had refused the last $\$ 1500$ and had been repaid only $\$ 2500$. Then he would have $\$ 2500$ unpaid new credit to set off against the $\$ 2500$ he had received. Hence, he could have kept $\$ 2500$; whereas by being repaid $\$ 4000$ he can keep only $\$ 1000$. In either case he would be only a general creditor for the balance. See the formula in note 33 supra.

35. A debtor may direct to which one of several debts a payment shall be applied, but if he fails to make a designation the creditor may apply it as he wishes. If both fail to designate, the law will decide. Standard Surety \& Casualty Co. of New York v. United States, 154 F.2d 335 (10th Cir. 1946). But circumstances may indicate the intended application of a payment. F. M. Slagle \& Co. v. Bushell, 70 S.D. 250, 16 N.W.2d 914 (1944).

Parties may by agreement change the application of payments previously made if no third person is prejudiced. United States v. Brent, 236 Fed. 771 (W.D.S.C. 1916) ; scc Smart v. Owen, 208 Ark. 662, 669, 187 S.W.2d 312, 315 (1945). However, if a debtor agreed to change the application of a payment from the new to an old debt, general creditors who would benefit by the repayment of the preferences might be considered prejudiced by the change of application.

36. Assume that $D$ owed $C$ a large debt that did not appear likely to be repaid. $C$ night agree to accept an interest bearing note in payment of the old debt and to extend new credit if $D$ promised to repay the new credit within 10 days of each new extension. Thus, all payments might be applied to the new credit when they could have been used just as easily to pay the old debt. Compare the facts in In re John Morrow \& Co., 134 Fed. 686 (S.D. Ohio 1901).

37. For example, assume that on Jan. 1, D owes $C \$ 5000$. On Jan. 15 , the four month period begins. On Jan. $16, D$ pays $C$ a $\$ 1000$ preference. On February $1, C$ extends new credit of $\$ 1000$ to $D$. On February $10, D$ pays $C \$ 1000$, specifically applying it to the February 1 advance according to an agreement between the parties. On March 1, April 1, 
The results apparentily required by Section $60 \mathrm{c}$ are undesirable. One objective of the Section $60 \mathrm{c}$ set-off is to encourage creditors to extend new credit to an insolvent debtor to help him avoid bankruptcy. Knowledge that the creditor can set off any new credit he extends after being preferred is designed to promote such credit extension. ${ }^{38}$ But Section $60 c$, if strictly applied, does not accomplish that objective when the new credit is repaid. Hence, the creditor cannot be sure of obtaining a set-off unless he has a large amount due from the debtor at the start of the four month period to which he can specifically apply all preferential payments. ${ }^{33}$ Of course, strict adherence to the statute means that more money is returned to the estate. But this money is coming from a creditor who, by advancing new credit, has tried to help the debtor and thus in turn aid other creditors. It seems unfair to force him to repay many of the preferences he has received since much of what he repays may then be distributed among other creditors who have not attempted to assist the debtor.0 Moreover, the statute discriminates against both new and old creditors to whom the debtor owes little or nothing at the start of the four month period. Since such creditors have no large prior amount due against which to set off preferences, they are forced to apply all current payments to the new credit. Thus there will be less unpaid new credit at the time of bankruptcy. Furthermore, the section discriminates against uninformed creditors. The

and May $1, C$ extends new credit of $\$ 1000$ and on March 10 and April $10, D$ sprcifically pays for the credit extended earlier in the month. Since all payments after the Jan. 16 preference were applied to the new credit, there is only $\$ 1000$ new credit remaining ungaid at the time of bankruptcy. $C$ will have to repay $\$ 3000$ and become a general ereditor for $\$ 8000$. If all payments had been applied to the old debt, $C$ would have $\$ \$ 000$ unpaid new credit to set off against the $\$ 4060$ preferences, and $C$ could keep $\$ 4000$ and become a general creditor for $\$ 5000$. Therefore, if few assets are available for general creditors, $C$ is harshly penalized for simply being uninformed.

38. See note 5 supra. Perhaps this presumes knowledge on the part of the crcultor which he does not in fact possess. Many creditors have probably never heard of a set-ofi of unpaid new credit and do not rely on $\$ 60 \mathrm{c}$ at all when they extend such credit. But a creditor who has extended credit to other debtors who have subsequently gone bankrupt may be quite aware of the dangers, and possible benefits, of $\$ 60 \mathrm{c}$. MIany trade creditors are in this position.

A creditor can never know that a payment is actually made within the four month period, and thus a voidable preference, since the period cannot be computed until it has ended, that is, when the petition in bankruptcy is filed. Hence, even though $C$ lnows $D$ is insolvent, he may not expect him to go into bankruptcy and therefore may not anticipate having to return any payments. However, the possibility that such payments may have to be repaid will influence the actions of many informed creditors.

39. In some cases $C$ may not be prejudiced if part of the payments are applied to the new credit. See note 33 supra.

40. The creditor whom $\S 60 \mathrm{c}$ favors has not depleted the estate by the full amount of the payments; he has depleted it only to the extent that the payments exceed the new credit extended within the four month period. Therefore, it would seem that he should be required to return only the excess. If he is forced to return all payments, he is maling a double surrender "in that he is required to give up the payments received and to lose the new credit extended" Walker v. Wilkinson, 296 Fed. 850, 853 (5th Cir. 1924). See Gans v. Ellison, 114 Fed. 734, 737 (3d Cir. 1902). 
informed creditor insists that payments be applied to any debt that arose prior to the four month period. ${ }^{41}$ Or he avoids the preference label altogether by demanding present consideration for any credit extended after he has reason to believe the debtor is insolvent. ${ }^{42}$ The uninformed creditor, who fails to take such precautions, is the one penalized by Section $60 \mathrm{c}^{43}$

To assure equitable treatment of creditors and to promote extension of new credit to insolvent debtors, Section $60 \mathrm{c}$ should be anended by deleting the words "remaining unpaid." Then it would no longer be vital to a creditor that only a certain amount be repaid or that payment be applied to a particular debt.44 The amendment should also provide that new credit may be set off only against prior preferential payments. ${ }^{45}$ This will discourage preferential payments, just before bankruptcy, large enough to cover new credit that has already been extended. ${ }^{46}$ Thus, the revised section should read:

"If a creditor has been preferred, and afterwards in good faith gives the debtor further credit without security of any kind for property which becomes a part of the debtor's estate, the amount of such new credit may be set off against the prior preferences which would otherwise be recoverable from him."

41. Thus the new credit is left unpaid and can be used as an off set. See notes 35-7 supra.

42. If a debtor intends to make payments, it may be possible for him to make them at the same time advances are made. Then the payments would not be preferences; they would be present consideration for part of such advances. Dean v. Davis, 242 U.S. 438 (1917) ; Gray v. Tantleff, 273 Fed. 524 (E.D.N.Y. 1921); In re Williams, 60 F. 2d 130 (D. Minn. 1932). See also 3 Collner, Bankruptcy $\uparrow 60.19$ (14th ed., Moore \& Oglebay, 1941). If a debtor cannot make payments at the time new credit is extended, the creditor, if he knows of the debtor's insolvency, makes the advance at his peril since any later payment may be a preference. See note 26 supra.

43. The penalty may be substantial and it will bear no relation to the degree of knowledge possessed by the creditor. There is no reason why the uninformed creditor should be discriminated against in this manner.

44. See text at notes $22-37$ sipra.

45. Most courts have already construed $\S 60 \mathrm{c}$ as applicable only to prior preferential payments. See, e.g., Robie v. Meyers Equipment Co., 114 F. Supp. 177 (D. Minu. 1953); Price v. Derbyshire Coffee Co., 128 App. Div. 472, 112 N.Y. Supp. 830 (1908). However, at least one court has applied a set-off to subsequent preferential payments. Walkcr $v$. Wilkinson, 296 Fed. 850 (5th Cir. 1924). Therefore, it seems desirable to anend the section to deal explicitly with this point.

46. If this provision were not inserted and a complete "net result" rule for all transactions within the four month period were adopted, the door would be open for large pay. ments to favored creditors just prior to bankruptcy. Such payments would be large enough and given expressly for the purpose of off setting any unused balance of new credit. 